\title{
UKŁADY ZBIOROWE PRACY A PRAWO ANTYMONOPOLOWE UNII EUROPEJSKIEJ I STANÓW ZJEDNOCZONYCH
}

\section{PROBLEMATYKA SOCJALNA W AKSJOLOGII PRAWA ANTYMONOPOLOWEGO}

Dokonanie precyzyjnego opisu aksjologii prawa antymonopolowego jest zadaniem trudnym. Polski Sąd Ochrony Konkurencji i Konsumentów trafnie wskazuje, że „,może budzić wątpliwości, co chroni, kogo chroni i kiedy chroni ustawa antymonopolowa" ${ }^{1}$. Najogólniej rzecz ujmując, stwierdzić można, że celem prawa antymonopolowego jest zapewnienie właściwego funkcjonowania rynku. Każda próba doprecyzowania tego stwierdzenia otwiera pole do niekończących się sporów. Z punktu widzenia niniejszych rozważań zasadnicze znaczenie ma odpowiedź na pytanie, czy w aksjologii prawa antymonopolowego mieści się dążenie do realizacji celów o charakterze socjalnym.

Rdzeń prawa antymonopolowego Unii Europejskiej współtworzą unormowania zakazujące nadużywania pozycji dominującej oraz zawierania porozumień ograniczających konkurencję ${ }^{2}$. R. O’Donoghue i A. J. Padilla podkreślają, że pierwsza ze wskazanych instytucji odnosi się do działań strategicznych zmierzających do rozszerzenia siły rynkowej dominującego przedsiębiorstwa, które szkodzą interesowi konsumentów ${ }^{3}$. Trudno byłoby zatem bronić tezy, iż problematyka socjalna powinna być brana pod uwage przy stosowaniu zakazu nadużywania pozycji dominującej.

Zagadnienia socjalne usuwane są również z problematyki zakazu zawierania porozumień ograniczających konkurencję. Na niepowodzenie skazane sa nawet próby inkorporowania problematyki socjalnej do analizy art. 101 ust. 3 Traktatu o funkcjonowaniu Unii Europejskiej (TfUE). Przepis ten stanowi, że postanowienia ustępu 1, które konstytuują zakaz zawierania porozumień ograniczających konkurencję, mogą zostać uznane za niemające zastosowania do:

\footnotetext{
${ }^{1}$ Wyrok z 18 grudnia 2002 r., sygn. akt XVII Ama 19/2001.

${ }^{2}$ Zgodnie z konwencja przyjętą w polskiej doktrynie, uznaje się, że w skład prawa antymonopolowego - obok zakazów nadużywania pozycji dominującej i zawierania porozumień ograniczających konkurencję - wchodzi również kontrola koncentracji przedsiębiorstw. Zagadnienia związane z ostatnią ze wskazanych instytucji nie mieszczą się w ramach tego opracowania.

${ }^{3}$ Por. R. O'Donoghue, A. J. Padilla, The Law and Economics of Article 82 EC, Oxford, Portland 2006, s. 174 .
} 
- każdego porozumienia lub kategorii porozumień między przedsiębiorstwami,

- każdej decyzji lub kategorii decyzji związków przedsiębiorstw,

- każdej praktyki uzgodnionej lub kategorii praktyk uzgodnionych, które przyczyniają się do polepszenia produkcji lub dystrybucji produktów bądź do popierania postępu technicznego lub gospodarczego, przy zastrzeżeniu dla użytkowników słusznej części zysku, który z tego wynika, oraz bez:

a) nakładania na zainteresowane przedsiębiorstwa ograniczeń, które nie sa niezbędne do osiągnięcia tych celów;

b) dawania przedsiębiorstwom możliwości eliminowania konkurencji w stosunku do znacznej części danych produktów.

Komisja Europejska w punkcie 32 Wytycznych dotyczących stosowania przedmiotowej instytucji stwierdza, że dokonując wykładni analizowanego przepisu, należy wziąc pod uwagę pozytywne ekonomiczne skutki danego porozumienia, praktyki uzgodnionej lub decyzji związków przedsiębiorstw (,the assessment of the positive economic effects of restrictive agreements") ${ }^{4}$. Trafny wydaje się więc pogląd C. Bernard, iż zgodnie z Wytycznymi, badając to, czy dane porozumienie podlega zwolnieniu od ogólnego zakazu zawierania porozumień ograniczających konkurencję, należy brać pod uwagę jedynie względy ekonomiczne (,,refers only to economic considerations which can be taken into account when deciding whether an agreement satisfies Art. 81 (3)"5).

Wiodacym nurtem w doktrynie i judykaturze Stanów Zjednoczonych pozostaje szkoła chicagowska. Aksjologicznym jądrem prawa antymonopolowego czyni ona wąsko rozumianą efektywność alokacyjną. Mimo że główny nurt szkoły chicagowskiej występuje obecnie w postaci znacznie bardziej wyważonej niż w latach osiemdziesiątych, jego przedstawiciele pozostaja wierni zapatrywaniu, iż uwzględnianie celów pozaekonomicznych w analizie antymonopolowej byłoby wyrazem nostalgii za protekcjonizmem i zazwyczaj szkodziłoby efektywności (,,To Chicagoans the only legitimate goal of antitrust is efficiency in resource allocation. Non-economic goals are nostalgic protectionism that usually impede efficiency"6). Bez ryzyka popełnienia błędu stwierdzić można zatem, że prawo antymonopolowe Stanów Zjednoczonych jest jeszcze bardziej „,zamknięte” na argumentację nawiązująca do kwestii socjalnych niż analogiczny zespół norm prawa Unii Europejskiej.

Usuwanie kwestii socjalnych z optyki prawa antymonopolowego może być uznane za powszechną tendencję. Warto tu zwrócić uwagę na doświadczenia Nowej Zelandii. Do 1986 r. za cel prawa antymonopolowego tego państwa uznawano realizację interesu publicznego. W tym okresie aksjologia prawa antymonopolowego Nowej Zelandii ujmowana była bardzo szeroko. Wykraczała ona zdecydowanie poza zagadnienia związane z konkurencja oraz efektyw-

${ }^{4}$ Guidelines to the Application of Article 81 (3) of the Treaty, OJ C 101, 27/4/2004, s. 97-118.

${ }^{5}$ C. Bernard, EC Employment Law, New York 2006, s. 767. Aksjologia polskiego prawa antymonopolowego jest podobna do systemu wartości prawa antymonopolowego Unii Europejskiej. Nie ma w szczególności podstaw do obrony tezy, iż w prawie polskim problematyka socjalna powinna być brana pod uwagę przy wykładni unormowań antymonopolowych.

${ }^{6}$ Por. G. E. Weston, New Trends in the US Antitrust Law: The Patent - Antitrust Interface as an Example, „International Review of Industrial Property and Copyright Law” 15, 1984, nr 3, s. 272. 
nością, a obejmowała między innymi dążenie do wzrostu zatrudnienia, sprzyjanie rozwojowi przemysłowi i eksportowi. R. J. Ahdar stwierdza, że prowadziło to do niewłaściwych skutków, i z aprobatą odnosi się reformy, która zawęziła aksjologię nowozelandzkiego prawa antymonopolowego ${ }^{7}$.

\section{SFERY ZGODNOŚCI AKSJOLOGICZNEJ POMIĘDZY ZBIOROWYM PRAWEM PRACY A PRAWEM ANTYMONOPOLOWYM}

W kontekście zagadnień poruszanych w artykule na szczególną uwagę zasługuje wypowiedź K. W. Barana, który badając problematykę zbiorowego prawa pracy stwierdza, że ,główną funkcją rokowań układowych jest zapew-

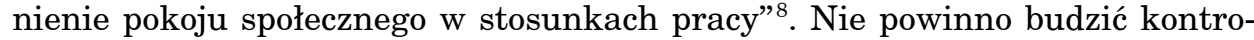
wersji stwierdzenie, że osiągnięcie ,,pokoju społecznego” zazwyczaj sprzyja właściwemu funkcjonowaniu gospodarki. W tej sferze funkcje zbiorowego prawa pracy korespondują z aksjologią prawa antymonopolowego.

Płaszczyzną, na której prawo pracy służy realizacji celów w pełni komplementarnych wobec aksjologii prawa antymonopolowego, jest tak zwane ustawodawstwo antykryzysowe ${ }^{9}$. Przykładowo wskazać tu można na rozwiązania przewidziane przez polską ustawę o łagodzeniu skutków kryzysu ekonomicznego dla pracowników i przedsiębiorców ${ }^{10}$. W art. 9 ust. 1 stanowi ona, że jeżeli jest to uzasadnione przyczynami obiektywnymi lub technologicznymi, lub dotyczącymi organizacji czasu pracy, okres rozliczeniowy może być przedłużony, nie więcej jednak niż do 12 miesięcy, przy zachowaniu ogólnych zasad dotyczących bezpieczeństwa i zdrowia pracowników. W doktrynie wskazuje się, że ,z punktu widzenia interesów pracodawcy określenie rozmiaru i sposobu organizacji czasu pracy, a więc okresów w których pracownik jest zobowiązany pozostawać w dyspozycji pracodawcy, stanowi jeden z głównych parametrów efektywności pracy"11. Podnoszenie efektywności pracy przekłada się naturalnie na poprawę szeroko rozumianej efektywności gospodarki, a tym samym sprzyja realizacji podstawowych założeń aksjologicznych prawa antymonopolowego.

Rozwiązanie przewidziane w art. 9 ust. 1 ustawy o łagodzeniu skutków kryzysu ekonomicznego dla pracowników i przedsiębiorców znajduje pełne uzasadnienie w aksjologii zarówno zbiorowego prawa pracy, jak i prawa antymonopolowego. Umożliwia ono minimalizację społecznych kosztów występowania okresów dekoniunktury przy jednoczesnej optymalizacji efektywności gospodarki.

${ }^{7}$ Por. R. J. Ahdar, The Role of Antitrust Policy in the Development of Australian-New Zealand Free Trade, „Northwestern Journal of International Law and Business” 12, 1991, s. 322.

${ }^{8}$ K. W. Baran, Zbiorowe prawo pracy. Komentarz, Warszawa 2010, s. 209.

${ }^{9}$ Por. K. W. Baran, Ogólna charakterystyka ustawodawstwa antykryzysowego na tle funkcji prawa pracy, „Praca i Zabezpieczenie Społeczne” 2009, nr 9, s. 18 i n.; A. Chobot, Nowe formy zatrudnienia. Kierunki rozwoju i nowelizacji, Warszawa 1997, s. 41 i 42.

${ }^{10}$ Ustawa z 1 lipca 2009 r., Dz. U. Nr 125, poz. 1035 ze zm.

11 J. Stelina, M. Zieleniecki, Regulacje antykryzysowe z zakresu prawa pracy, „Praca i Zabezpieczenie Społeczne" 2009, nr 11, s. 15. 


\section{OBSZARY NAPIECCIA MIEDZY FUNKCJAMI ZBIOROWEGO PRAWA PRACY A AKSJOLOGIA PRAWA ANTYMONOPOLOWEGO}

Podsumowując dotychczasowe rozważania aksjologiczne, stwierdzić można, iż we wszystkich badanych systemach prawnych prawo antymonopolowe i zbiorowe prawo pracy ukierunkowane są na realizację odmiennych wartości. $\mathrm{Na}$ niektórych płaszczyznach prowadzi to do powstania aksjologicznego napięcia pomiędzy tymi zespołami norm, które przekładać może się na trudności w sferze stosowania prawa ${ }^{12}$. Na szczególną uwagę zasługują kwestie zgodności z prawem antymonopolowym działalności związków zawodowych i legalności postanowień układów zbiorowych, które prowadzą do podniesienia kosztów pracy, problem wpływu układów zbiorowych na konkurencję poza płaszczyzną relacji między pracownikami a pracodawcami oraz zagadnienie dopuszczalności wykorzystania instrumentów antymonopolowych do podważenia sprzecznych $\mathrm{z}$ interesem pracowników postanowień układów zbiorowych pracy.

\section{Podnoszenie kosztów pracy na skutek zawierania układów zbio- rowych pracy i działalności związków zawodowych $w$ analizie antymonopolowej}

Po przyjęciu ustawy Shermana (1890) amerykańskie sądy zaczęły kwestionować zgodność z prawem antymonopolowym działalności związków zawodowych. Szczególnie duże znaczenie miało wydawanie przez sądy injunctions skierowanych przeciwko organizacjom pracowniczym. Zastosowanie tego środka prawnego umożliwiało łamanie strajków. Pewne wyobrażenie o znaczeniu wskazanego instrumentu daje to, że pomiędzy 1880 a $1930 \mathrm{r}$. wydano około 4300 injunctions. Sąd Najwyższy Stanów Zjednoczonych zaaprobował tę linię judykatury w wyroku w sprawie In Re Debs ${ }^{13}$.

W orzecznictwie Federalnego Sądu Najwyższego za dopuszczalne uznano także dochodzenie na podstawie prawa antymonopolowego odszkodowań od przywódców związków zawodowych za szkody powstałe w wyniku podejmowanych przez nie działań w obronie praw pracowniczych ${ }^{14}$.

Po to, aby ochronić organizacje pracownicze przed roszczeniami antymonopolowymi, Kongres wprowadził stosowne regulacje do ustawy Claytona (1914). Na ich podstawie nie można kwestionować zgodności $\mathrm{z}$ ustawa

12 Pierwsze napięcia pomiędzy kształtującym się prawem antymonopolowym a ochroną interesów socjalnych pracowników najemnych pojawiły się już w średniowieczu. M. Furse zwraca uwagę, że z procesem powstawania prawa antymonopolowego kojarzyć można unormowania przyjęte w Anglii po epidemii dżumy. W okresie tym wystąpił poważny niedostatek siły roboczej, co doprowadziło do sprzecznego w interesem właścicieli ziemskich wzrostu wynagrodzeń pracowników najemnych. Celem przyjętych wówczas rozwiązań legislacyjnych było m.in. utrzymanie wynagrodzeń pracowników i cen na poziomie sprzed fali masowych zgonów. M. Furse stwierdza nawet, że obowiązująca w prawie Stanów Zjednoczonych reguła, zgodnie z która poszkodowany naruszeniem prawa antymonopolowego może dochodzić potrójnego odszkodowania, ma korzenie w Statute of Labourers z 1349 r.; M. Furse, Competition Law of the EC and UK, Oxford 2004, s. 3.

13158 U.S. 564 (1895).

${ }^{14}$ Sprawa Loewe v. Lawor, 208 U.S. 274 (1908). 
Shermana samego istnienia związków zawodowych oraz niektórych form aktywności związkowej. Zgodnie $\mathrm{z}$ art. 6 ustawy Claytona, ,„praca człowieka nie jest towarem ani przedmiotem handlu. Żadnych przepisów zawartych $\mathrm{w}$ ustawach antymonopolowych nie wolno interpretować w sposób zakazujący istnienia i działania organizacji robotniczych, rolniczych lub ogrodniczych, które utworzone zostały w celu udzielania sobie wzajemnej pomocy i nie posiadaja kapitału, ani nie maja na celu osiagnięcia zysku, ani jako zabraniających lub ograniczających indywidualnych członków takich organizacji $\mathrm{w}$ legalnym wypełnianiu prawnie uzasadnionych celów tych organizacji. Organizacji takich (ani ich członków) nie wolno uznawać za nielegalne związki lub zmowy, powodujące ograniczenie handlu w rozumieniu ustaw antymonopolowych" ${ }^{15}$. Ustawa Claytona ograniczała również stosowanie injunctions wobec organizacji pracowniczych.

W amerykańskim orzecznictwie ustawę Claytona interpretowano jednak w sposób bardzo niekorzystny dla związków zawodowych. Wiele rozstrzygnięć sądowych szło tak daleko, że praktycznie pozbawiały prosocjalne postanowienia ustawy Claytona treści normatywnych ${ }^{16}$.

Odpowiadając na antypracowniczą linię judykatury, amerykański ustawodawca przyjął ustawę Norris-LaGuardia (1932), która sformułowana została w sposób znacznie bardziej precyzyjny niż wskazane unormowania ustawy Claytona. Oba wskazane akty normatywne tworzą rdzeń tak zwanego ustawowego wyłączenia pracy (statutory labor exemption) spod ograniczeń antymonopolowych.

Po przyjęciu ustawy Norris-LaGuardia judykatura zaakceptowała, a nawet poszerzyła zakres statutory labor exemption. Za zgodne z prawem antymonopolowym zaczęto uznawać w szczególności strajki i bojkoty. Sądy nie uwzględniały również roszczeń odszkodowawczych wysuwanych wobec przywódców związkowych ${ }^{17}$.

Zauważyć należy, iż statutory labor exemption nie przesądza o legalności układów zbiorowych pracy - umów zawieranych między związkami zawodowymi a podmiotami niemającymi charakteru pracowniczego (nonlabor parties). Porozumienia tego typu często zawierają postanowienia, które ograniczają konkurencję, co może wywoływać wątpliwości dotyczące ich zgodności z prawem antymonopolowym. W judykaturze wykształciła się jednak koncepcja non-statutory labour exemption ${ }^{18}$. Jej teoretyczne uzasadnienie

15 Tłumaczenie za: Pozaeuropejskie ustawy antymonopolowe, Warszawa 1995, s. 52. „The labor of a human being is not a commodity or article of commerce. Nothing contained in the antitrust laws shall be construed to forbid the existence and operation of labor, agricultural, or horticultural organizations, instituted for the purposes of mutual help, and not having capital stock or conducted for profit, or to forbid or restrain individual members of such organizations from lawfully carrying out the legitimate objects thereof; nor shall such organizations, or the members thereof, be held or construed to be illegal combinations or conspiracies in restraint of trade, under the antitrust laws".

${ }^{16}$ Por. J. Hoffmeyer, Fourth Down and an Appeal: The Nonstatutory Exemption to Antitrust Law in Clarett v. National Football League, ,,Sports Lawyers Journal” 13, 2006, s. 195; Duplex Printing Press Co. v. Deering, 254 U.S. 443 (1921); American Steel Foundries v. Tri-Central Trades 257 U.S. 184 (1921).

${ }^{17}$ Por. sprawę Apex Hosiery Co. v. Leader, 310 U.S. 469, 492, 494 (1940).

18 Por. J. Hoffmeyer, op. cit., s. 198. L. P. Masteralexis, Antitrust Law: Professional Sport Applications, w: D. J. Cotton, J. T. Wolohan (red.), Law for Recreation and Sport Managers, Dubuque - Iowa 2007, s. 634 . 
stanowi założenie, iż ustawodawca wspiera zawieranie układów zbiorowych pracy, gdyż umożliwia to osiagnięcie pokoju społecznego (labor peace). Wskazać należy przy tym, że w prawie amerykańskim zakres non-statutory labor exemption nie jest jasno określony. Zagadnienie to zostało omówione bliżej w punkcie III.2.

Próbę rekonstrukcji ogólnych założeń aksjologicznych prawa Unii Europejskiej dotyczących relacji między prawem antymonopolowym a zagadnieniami socjalnymi rozpocząc należy od zwrócenia uwagi na koncepcję społecznej gospodarki rynkowej.

Bezpośrednie odniesienie do konstrukcji społecznej gospodarki rynkowej zostało wprowadzone do Traktatu o Unii Europejskiej (TUE) przez Traktat z Lizbony. W aktualnym brzmieniu art. 3 ust. 3 zdanie 2 TUE stanowi, że Unia działa na rzecz trwałego rozwoju Europy, którego podstawą jest zrównoważony wzrost gospodarczy oraz stabilność cen, społeczna gospodarka rynkowa o wysokiej konkurencyjności zmierzająca do pełnego zatrudnienia i postępu społecznego oraz wysoki poziom ochrony i poprawy jakości środowiska. Zwrócić należy również uwagę na to, że w myśl art. 20 Konstytucji Rzeczypospolitej Polskiej, społeczna gospodarka rynkowa oparta na wolności działalności gospodarczej, własności prywatnej oraz solidarności, dialogu i współpracy partnerów społecznych stanowi podstawę ustroju gospodarczego Rzeczypospolitej Polskiej.

O dużym znaczeniu koncepcji społecznej gospodarki rynkowej dla funkcjonowania prawa antymonopolowego Unii Europejskiej świadczyć mogą wywody byłego komisarza do spraw konkurencji, M. Montiego. Jeszcze przed wejściem w życie Traktatu z Lizbony podkreślał on, że unijne (wspólnotowe) prawo antymonopolowe funkcjonuje w kontekście tak zwanego Modelu Europejskiego, na którego ukształtowanie silny wpływ wywarła koncepcja społecznej gospodarki rynkowej ${ }^{19}$. W doktrynie wskazuje się, że podstawowymi elementami tej koncepcji są między innymi unormowania antymonopolowe i przepisy dotyczące układów zbiorowych pracy ${ }^{20}$.

W prawie unijnym problematyka socjalna, a w szczególności kwestia obrony zbiorowych interesów pracowników i pracodawców ${ }^{21}$, znajduje głębokie zrozumienie. Dla określenia granic interwencji antymonopolowej duże znaczenie ma art. 155 ust 1 TfUE. Stanowi on, że dialog między partnerami społecznymi na poziomie unijnym może prowadzić, jeśli oni sobie tego życzą, do nawiązania stosunków umownych, w tym umów zbiorowych.

Warto również zwrócić uwagę na art. 6 ust. 3 TUE, który stanowi, że prawa podstawowe, zagwarantowane $\mathrm{w}$ europejskiej Konwencji o ochronie praw człowieka i podstawowych wolności oraz wynikające z tradycji konstytucyjnych wspólnych państwom członkowskim, stanowią część prawa Unii jako zasady

${ }^{19}$ Por. M. Monti, referat Competition in a Social Market Economy wygłoszony na Konferencji „Reforma Europejskiego Prawa Konkurencji” we Freiburgu w dniach 9-10 listopada 2000 r., dostępny na: http://www.docstoc.com.

${ }^{20}$ T. Włudyka, Społeczna gospodarka rynkowa. Podstawy prawno-gospodarcze, w: Dziedzictwo prawne XX wieku. Ksiega pamiatkowa z okazji 150-lecia TBSP UJ, komitet redakcyjny: A. Zoll, J. Stelmach, J. Halberda, Kraków 2001, s. 322.

${ }^{21}$ Por. art. 151 i 151 ust. 1 TfUE. 
ogólne prawa. W tym kontekście wskazać należy na art. 59 ust. 2 Konstytucji RP. Zgodnie z nim związki zawodowe oraz pracodawcy i ich organizacje maja prawo do rokowań, w szczególności w celu rozwiązywania sporów zbiorowych, oraz do zawierania układów zbiorowych pracy i innych porozumieńn ${ }^{22}$.

Porównując zasady interwencji antymonopolowej w problematykę socjalna w prawie Unii Europejskiej i Stanów Zjednoczonych, pamiętać należy, iż pierwszy z tych zespołów norm jest znacznie młodszy. Proces budowy wspólnotowego (unijnego) prawa antymonopolowego rozpoczął się w okresie, gdy zasadnicze zręby europejskiego modelu społeczno-gospodarczego były już ustalone. W systemie wspólnotowym (unijnym) takie zagadnienia, jak zgodność z prawem antymonopolowym samego istnienia związków zawodowych czy dopuszczalność podejmowania przez nie akcji strajkowych, nigdy nie budziły żadnych wątpliwości ${ }^{23}$.

Wskazać należy także, że zawarte $\mathrm{w}$ prawie unijnym postanowienia dotyczące zagadnień socjalnych i prawa antymonopolowego mają tę samą rangę. Nie można zatem mechanicznie stawiać jednego z tych zespołów norm ponad drugim.

Trybunał Sprawiedliwości (TS) w wyroku w sprawie Albany International $B V^{24}$ wskazał, że ,wprawdzie pewne skutki w postaci ograniczenia konkurencji są nieodłączne od porozumień zbiorowych zawieranych między reprezentatywnymi organizacjami pracodawców i pracobiorców, jednakże realizacja celów z zakresu polityki społecznej, jakim służą tego rodzaju porozumienia, byłaby poważnie zagrożona, gdyby partnerzy społeczni podlegali art. 85 ust. 1 traktatu [obecnie art. $101 \mathrm{TfUE} \mathrm{-} \mathrm{M.K.K.],} \mathrm{poszukując} \mathrm{wspólnie} \mathrm{sposobów} \mathrm{poprawienia}$ warunków zatrudnienia i pracy. Zatem ze spójnej i celowościowej wykładni wszystkich istotnych postanowień traktatu wynika, że porozumienia zawarte w ramach zbiorowych uzgodnień między partnerami społecznymi dla realizacji takich celów należy uznać, ze względu na ich charakter i przedmiot, za niepodlegające art. 85 ust. 1 traktatu [obecnie 101 ust. 1 TfUE - M.K.K.]”.

Linia rozumowania wytyczona w wyroku w sprawie Albany International $B V$ została potwierdzona i rozwinięta w późniejszym orzecznictwie. W szczególności w sprawie Drijvende Bokken $B V^{25}$ Trybunał niemal dosłownie powtórzył kluczowe fragmenty uzasadnienia orzeczenia w sprawie Albany International $B V$. Trybunał podkreślił, że badane porozumienie było wynikiem dialogu społecznego między pracownikami a pracodawcami i zostało zawarte jako układ zbiorowy pracy. Zaakcentowano również fakt, że przedmiotowe porozumienie zmierzało do poprawy warunków zatrudnienia.

${ }^{22}$ Por. W. Sanetra, Konstytucyjne prawo do rokowań, „Praca i Zabezpieczenie Społeczne” 1998, nr 12, s. 3; K. W. Baran, Zbiorowe prawo pracy. Komentarz, Warszawa 2010, s. 207.

${ }^{23}$ Dla porównania warto wskazać, że - jak zauważają E. Nowińska i M. du Vall - stosowanie ustawy o zwalczaniu nieuczciwej konkurencji „,w odniesieniu do oceny działań związków zawodowych” jest wyłączone, ,,ale tylko w zakresie, w jakim działania te są zgodne z przepisami o rozwiązywaniu sporów zbiorowych" (E. Nowińska, M. du Vall, Ustawa o zwalczaniu nieuczciwej konkurencji, Warszawa 2011, s. 187-188).

24 C-67/96.

25 C-219/97. 
W uzasadnieniu wyroku w sprawie van der Woude ${ }^{26}$ znajduje się stwierdzenie, że porozumienia zawarte $\mathrm{w}$ ramach rokowań zbiorowych między pracodawcami a pracownikami i zmierzające do zwiększenia zatrudnienia oraz poprawy warunków pracy muszą, ze względu na ich naturę i cel, być uważane za niemieszczące się w zakresie obecnego art. 101 ust. 1 TfUE (,,agreements entered into in framework of collective bargaining between employers and employees and intended to improve employment and working conditions must, by virtue of their nature and purpose, be regarded as not falling within the scope of Article 85 (1) of the Treaty").

W orzecznictwie unijnym za ustalone uznać można, że zawarcie układu zbiorowego pracy nie stanowi naruszenia unijnego prawa antymonopolowego, o ile służy ono osiagnięciu celów polityki społecznej ${ }^{27}$. Można zatem mówić o swoistym immunitecie przysługującym układom zbiorowym pracy. Jego zakres obejmuje postanowienia układowe, których oddziaływanie na gospodarkę ogranicza się do podniesienia kosztów pracy ${ }^{28}$.

\section{Analiza antymonopolowa postanowień zbiorowych układów pracy, które oddziałuja na konkurencję poza płaszczyzna relacji między pracownikami a pracodawcami}

We wcześniejszych rozważaniach wskazano, że sam fakt doprowadzenia do podniesienia kosztów pracy $\mathrm{w}$ wyniku zawarcia układu zbiorowego pracy w systemie unijnym nie stanowi naruszenia prawa antymonopolowego. Kwestia kontrowersyjna jest natomiast dopuszczalność stosowania unijnego prawa antymonopolowego wobec tych postanowień układów zbiorowych pracy, które oddziałują na gospodarkę poza płaszczyzną relacji między pracownikami a pracodawcami ${ }^{29}$. Dla zilustrowania tej kwestii warto zwrócić uwagę na rozwiązania przyjęte $\mathrm{w}$ polskim Kodeksie pracy ${ }^{30}$. W art. $9 \S 1$ stanowi on, że ilekroć w tym akcie normatywnym jest mowa o prawie pracy, rozumie się przez to przepisy Kodeksu pracy oraz przepisy innych ustaw i aktów wykonawczych, określające prawa i obowiązki pracowników i pracodawców, a także postanowienia układów zbiorowych pracy i innych opartych na ustawie porozumień zbiorowych, regulaminów i statutów określających prawa i obowiązki stron stosunku pracy.

W myśl art. 240 § 1 Kodeksu pracy układ określa:

1) warunki, jakim powinna odpowiadać treść stosunku pracy, z tym że układ nie może naruszać praw osób trzecich $(\S 3)$;

26 C-222/98.

${ }^{27}$ Por. Z. Wiśniewski, Kierunki i skutki deregulacji rynku pracy w krajach Unii Europejskiej, Toruń 1999, s. 13.

${ }^{28}$ Por. orzeczenia w sprawach: Albany International BV; Drijvende Bokken BV; Van den Woude.

${ }^{29}$ Rzecznik generalny F. G. Jacobs w sprawie Albany International BV stwierdził nawet, że twórcy Traktatu albo nie byli świadomi istnienia problemów związanych z relacjami pomiędzy prawem antymonopolowym a układami zbiorowymi pracy, albo nie mogli dojść do porozumienia co do sposobu ich rozwiązania.

${ }^{30}$ Ustawa z 26 czerwca 1974 r., Dz. U. Nr 24, poz. 141 ze zm (dalej: k.p.). 
2) wzajemne zobowiązania stron układu, w tym dotyczące stosowania układu i przestrzegania jego postanowień.

Zgodnie z art. $240 \S 2$ k.p., układ może określać inne sprawy poza wymienionymi w $\S 1$, nieuregulowane w przepisach prawa pracy w sposób bezwzględnie obowiązujący.

J. Wratny wskazuje, że na treść układu składają się postanowienia normatywne, obligatoryjne i tak zwane inne ${ }^{31}$. W ostatniej ze wskazanych kategorii mieszczą się ,,zagadnienia z dziedziny prawa pracy poza granicami treści indywidualnych stosunków pracy. W rachubę wchodzą tu przede wszystkim tak zwane obowiązki pracodawcy względem załogi, szczególnie prowadzenie działalności socjalnej na rzecz załogi, na przykład pracodawca może być na mocy układu zbiorowego zobowiązany do otwarcia stołówki, żłobka lub przedszkola” ${ }^{32}$. Natomiast G. Goździewicz podkreśla, że ,„poza postanowieniami odnoszącymi się do treści stosunku pracy układ może regulować inne sprawy związane z praca i z reguły będą one dotyczyły pozaumownej części statusu pracownika. Warunek, jaki stawia tutaj ustawodawca, sprowadza się do stwierdzenie, by kwestie te nie były normowane w przepisach prawa pracy w sposób bezwzględnie obowiązujący" ${ }^{33}$. Autor ten, uszczegóławiając swoje rozważania, zauważa, że ,dziedziną, która może znaleźć [...] odzwierciedlenie w ramach postanowień układowych, jest problematyka ubezpieczeń społecznych [...]. Problem ten znany jest w wielu ustawodawstwach państw zachodnich" ${ }^{34}$. W orzecznictwie unijnym najwięcej wątpliwości co do zgodności z prawem antymonopolowym budziły postanowienia układowe dotyczące ubezpieczeń $^{35}$.

W prawie polskim należy zwrócić uwagę na porozumienia zbiorowe oparte na ustawie. Z. Niedbała trafnie zauważa, że ,,[w] świetle 9 \& 1 k.p. obok układów zbiorowych pracy i na identycznym poziomie w hierarchii szczególnych źródeł prawa pracy usytuowane zostały porozumienia zbiorowe. Powyższa kwalifikacja porozumień zbiorowych odnosi się jednak tylko do tych, które oparte sa na ustawie, a więc ich zawieranie w określonych warunkach przewidują wyraźnie przepisy rangi ustawowej. Stronami takiego porozumienia sa pracodawcy oraz organizacje związków zawodowych" ${ }^{36}$.

$\mathrm{Z}$ wypowiedzi rzecznika generalnego F. G. Jacobsa w sprawie Albany International $B V$ wywieść można, że immunitet chroniący układy zbiorowe pracy przed interwencją antymonopolową znajduje zastosowanie tylko wówczas, gdy kumulatywnie spełnione są następujące kryteria:

\footnotetext{
${ }^{31}$ Por. J. Wratny, Przepisy ogólne, w: Zbiorowe prawo pracy. Komentarz, Warszawa 2009, s. 149-160.

32 Ibidem, s. 157.

${ }^{33}$ G. Goździewicz, Uktady zbiorowe pracy. Komentarz, Bydgoszcz 1994, s. 63. Por. też K. Kolasiński, Prawo pracy $i$ zabezpieczenia spotecznego, Torun 2003, s. 354; B. Cudowski, Charakter prawny porozumień zbiorowych, „Państwo i Prawo” 1998, z. 8, s. 67.

${ }^{34}$ G. Goździewicz, Uktady zbiorowe pracy. Komentarz..., s. 66.

${ }^{35}$ Por. sprawa Albany International $B V$.

${ }^{36}$ Z. Niedbała, Porozumienia zbiorowe oparte na ustawie, w: idem (red.), Prawo pracy, Warszawa
} 2010 , s. 73 . 
- badane porozumienie spełnia wszelkie wymagania stawiane zbiorowym układom pracy;

- układ zawarty został w dobrej wierze;

- przedmiotem układu sa warunki płacy i pracy - postanowienia stanowiące rdzeń zbiorowych negocjacji;

- układ nie wpływa bezpośrednio na sytuację przedsiębiorstw nie będących jego strona.

W ujęciu zaproponowanym przez rzecznika generalnego F. G. Jacobsa zwolnieniu spod ograniczeń antymonopolowych nie podlegają natomiast porozumienia, których zasadniczą funkcja jest ograniczenie konkurencji między przedsiębiorstwami.

Wywody Trybunału Sprawiedliwości zawarte w uzasadnieniu wyroku w sprawie Albany idą w kierunku wytyczonym przez rozważania rzecznika generalnego, choć nie są tak pogłębione. Nie pozwalają one w szczególności na ustalenie tego, gdzie kończy się sfera objęta wyłączeniem spod zastosowania prawa antymonopolowego.

W sprawie van der Woude rzecznik generalny N. Fenelly podją ważną próbę doprecyzowania zakresu immunitetu chroniącego układy zbiorowe pracy przed ograniczeniami wynikającymi w prawa antymonopolowego. Stwierdził on, że immunitet ten powinien być ujmowany wąsko, a przy ustalaniu jego granic należy respektować zasadę proporcjonalności (,,exceptions established in the Albany cases must be narrowly constructed and, in particular, must respect the principle of proportionality"). Trybunał nie odniósł się do wskazanych teoretycznych dywagacji rzecznika generalnego i wydał wyrok opierający się na dotychczasowym orzecznictwie.

Przechodząc na grunt prawa polskiego, podkreślić należy, że powołane wypowiedzi Trybunału Sprawiedliwości i rzeczników generalnych dotyczą nie tylko układów zbiorowych pracy $\mathrm{w}$ rozumieniu Kodeksu pracy, ale również porozumień zbiorowych opartych na ustawie (9 § 1 k.p.).

W myśl amerykańskiej koncepcji zwolnień układów zbiorowych niewynikających z ustawy (non-statutory labor exemption), ich postanowienia uznaje się za zgodne z prawem antymonopolowym, jeżeli:

- poszkodowany ,ograniczeniem handlu” wynikajacym z układu zbiorowego jest jego strona;

- przedmiotem układu sa zagadnienia stanowiące obowiązkowy przedmiot negocjacji (mandatory subject of bargaining), a w szczególności czas pracy, wysokość płac i inne warunki zatrudnienia;

- stronami porozumienia sa niezależne podmioty dysponujące porównywalną siłą negocjacyjna, które działały w dobrej wierze (bona fide arm's lenth bargaining $)^{37}$.

\footnotetext{
${ }^{37}$ Por. sprawy: U.S. v. Hutcheson 312 U.S. 219 (1941); Allen Bradley Co. v. Local Union No. 3, International Brotherhood of Electrical Workers, 325 U.S. 797 (1945); Amalgamated Meat Cutters \& Butcher Workmen of North America v. Jewel Tea Co., 381 U.S. 676 (1965); United Mine Workers v. Pennington, 381 U.S. 657 (1965).
} 


\section{Wykorzystanie instrumentów antymonopolowych do podważenia sprzecznych $\mathrm{z}$ interesem pracowników postanowień układów zbiorowych pracy}

$\mathrm{Na}$ szczególną uwagę zasługują wypadki, w których amerykańska koncepcja non-statutory labor exemption wykorzystywana jest do obrony interesów pracodawców przed roszczeniami antymonopolowymi wysuwanymi przez pracowników. Warto tu wskazać na walkę zawodników największej ligi footballu amerykańskiego - NFL o większą swobodę kontraktową.

W serii spraw, które pojawiły się przed sądami Stanów Zjednoczonych, sportowcy za pomoca prawa antymonopolowego usiłowali podważyć skuteczność ograniczeń wiążących ich na trwałe z konkretnymi klubami ${ }^{38}$. Kluby przez długi czas skutecznie podważały możliwość zastosowania prawa antymonopolowego, powołując się na non-statutory labor exemption. Wskazywały one, że kwestionowane rozwiązania zostały przewidziane przez układ zbiorowy, który został zawarty przez nie ze związkiem graczy NFLPA. W wyroku w sprawie Powell v. NFL sąd stwierdził nawet, że upływ czasu, na który zawarty był układ zbiorowy, nie prowadzi jeszcze automatycznie do powstania możliwości podważenia spornych postanowień na podstawie prawa antymonopolowego. Uzasadnieniem tego stanowiska był pogląd, że w tego typu przypadkach strony dotychczasowego układu maja obowiązek prowadzenia negocjacji w celu zawarcia nowego porozumienia ${ }^{39}$. We wskazanym orzeczeniu stwierdzono również, że wystąpienie z roszczeniami antymonopolowymi nie jest dopuszczalne aż do wygaśnięcia ,,stosunku zbiorowych negocjacji” (,,until a collective bargaining relationship no longer exists" ${ }^{40}$. Po to, aby doprowadzić do zakończenia tej relacji, organizacja skupiająca graczy footballu amerykańskiego (NFPLA) została zmuszona do rezygnacji ze statusu ich reprezentanta w rokowaniach zbiorowych ${ }^{41}$.

Analiza sporu pomiędzy zawodnikami footballu amerykańskiego a klubami wskazuje, że w prawie Stanów Zjednoczonych zdarza się, iż kwestionowanie zgodności układów zbiorowych z prawem antymonopolowym jest korzystne dla pracowników. Objęcie całej treści układu zbiorowego absolutnym immunitetem chroniącym przed ingerencja antymonopolową może być zatem rozwiązaniem sprzecznym zarówno z aksjologią prawa pracy, jak i prawa antymonopolowego.

W prawie Unii Europejskiej wystapienie sytuacji, w których pracownicy podważaliby treść układów zbiorowych, powołując się na prawo antymonopolowe, jest mało prawdopodobne. Dla zilustrowania tej kwestii warto zwrócić uwagę na prawo polskie. Przewidziane w nim zasady zawierania

${ }^{38}$ Por. m.in. sprawy: Mackey v. NFL, 543 F.2d 606 (8th Cir. 1976); McCourt v. California Sport Inc., 600 F.2d 1193 (6th Cir. 1979); Bridgeman v. NBA, 675 F.Supp. 960 (D.N.J. 1987); Powell v. NFL, 930 F.2d 1293 (8th Cir. 1989).

${ }^{39}$ Por. G. M. Wong, Essentials of Sports Law, Westport, Connecticut, London 2002, s. 477.

${ }^{40}$ Por. S. C. Backman, NFL Players Fight for Their Freedom: The History of Free Agency in the NFL, „Sports Lawyers Journal” 9, 2002, s. 26.

${ }^{41}$ Por. wyroki w sprawach: McNiel v. NFL, 790 F.Supp. 871 (D. Minn. 1992); Jackson v. NFL, 802 F.Supp. 226 (D. Minn. 1992); White v. NFL, 836 F.Supp. 1458 (D. Minn. 1993). 
i obowiązywania układów zbiorowych pracy korespondują z wymaganiami przewidzianymi przez prawo antymonopolowe. Wskazać należy w szczególności, że układ nie może naruszać praw osób trzecich (art. 240 § 3 k.p.), a każda ze stron jest zobowiązana do prowadzenia rokowań w dobrej wierze i z poszanowaniem słusznych interesów drugiej strony (art. $241^{3} \S 1$ k.p.). Co więcej, układ podlega wpisowi do rejestru (art. $241^{11} \S 1$ k.p.) i nie może wejść $\mathrm{w}$ życie wcześniej niż z dniem zarejestrowania (art. $241^{12} \S 1$ k.p. $)^{42}$. Postanowienia sprzeczne $\mathrm{z}$ prawem, $\mathrm{w}$ tym również sprzeczne $\mathrm{z}$ prawem antymonopolowym, nie powinny być rejestrowane (art. $24111 \S 3$ k.p.). Jeżeli jednak zostaną wpisane do rejestru, moga zostać $\mathrm{z}$ niego usunięte $\mathrm{w}$ określonej w Kodeksie pracy procedurze (art. $241^{11} \S 51-241^{11} \S 55$ k.p.).

Ryzyko naruszenia prawa antymonopolowego jest nieco wyższe, choć także niewielkie, jeśli chodzi o porozumienia zbiorowe oparte na ustawie. Źródłem pewnych zagrożeń może być w szczególności to, że ,,[w] przeciwieństwie [...] do układów zbiorowych pracy przepisy Kodeksu pracy nie zawieraja żadnych unormowań dotyczących zasad i trybu zawierania [...] porozumień [zbiorowych opartych na ustawie - M.K.K.], a także - co warto podkreślić - nie odsyłaja w żadnym zakresie do odpowiedniego stosowania przepisów kodeksowych dotyczących układów zbiorowych. Można zatem uznać, że przynajmniej $\mathrm{w}$ sensie prawnym partnerzy społeczni w postępowaniu zmierzającym do zawarcia porozumienia nie sa obowiązani do respektowania zasady wzajemnej lojalności [...]. Treść zawartego przez strony porozumienia nie podlega też kontroli jego legalności w postępowaniu rejestrowym" ${ }^{43}$.

\section{PODSUMOWANIE}

Problematyka socjalna nie jest brana pod uwagę przy rekonstrukcji aksjologii ani unijnego, ani amerykańskiego prawa antymonopolowego. $\mathrm{Na}$ niektórych obszarach aksjologia prawa antymonopolowego jest w pełni zgodna z systemem wartości, którego realizacji służy zbiorowe prawo pracy, na innych zaś pomiędzy wskazanymi zespołami norm występuja pewne napięcia.

Obecnie sam fakt podniesienia kosztów pracy w wyniku działalności związków zawodowych, a zwłaszcza zawarcia układu zbiorowego nie może być kontestowany z punktu widzenia prawa antymonopolowego. Kwestia ta nigdy nie budziła wątpliwości w judykaturze unijnej (wspólnotowej), a po pewnych wahaniach została zaakceptowana w systemie Stanów Zjednoczonych.

Zakres pełnego immunitetu chroniącego układy zbiorowe pracy przed interwencją antymonopolową nie rozciąga się na te ich postanowienia, które oddziałują na funkcjonowanie rynków poza płaszczyzną relacji między pracownikami a pracodawcami. Unijne i amerykańskie orzecznictwo wypracowało

\footnotetext{
${ }^{42}$ Por. L. Kaczyński, Charakter prawny uktadów zbiorowych pracy, „Państwo i Prawo” 1996, z. 7, s. 28; G. Goździewicz, Uktady zbiorowe pracy. Regulamin wynagradzania. Regulamin pracy, Bydgoszcz 1996, s. 121.

${ }^{43}$ Z. Niedbała, op. cit., s. 73.
} 
ogólne reguły dotyczące zasad interwencji antymonopolowej w tej sferze. Zasady te nie są jednak na tyle precyzyjne, by było można stwierdzić, że udało się wyeliminować wszelkie istotne wątpliwości prawne.

Linia judykatury Stanów Zjednoczonych w sporach, w których pracownicy usiłuja podważyć postanowienia układów zbiorowych pracy, powołując się na prawo antymonopolowe, nie jest w pełni jasna. Podobne sprawy nie były natomiast rozpatrywane przez sądy unijne, a prawdopodobieństwo ich pojawienia się przed nimi lub przed sądami państw członkowskich jest niewielkie.

dr hab. Marek Krzysztof Kolasinski

Uniwersytet Mikotaja Kopernika w Toruniu

\section{COLLECTIVE LABOUR AGREEMENTS AND THE EUROPEAN UNION AND THE UNITED STATES ANTITRUST LAW}

\section{Summary}

Although social concerns are strongly present in the laws of the European Union and the United States, antitrust, or competition, law whose predominant objective is securing the correct working of the competition mechanism, constitutes a vital element of both legal systems.

Social concerns remain outside the scope of antitrust (competition) law, which may lead to a very complicated situation between that law and social regulations. There are fields in which those sets of rules are complementary, yet it must be underlined that in some areas the objectives of labour law are different from, and even contrary to, the aims of antitrust (competition) law. The area most sensitive to potential conflicts are the regulations of labour law which are connected with collective bargaining.

According to the EU and US law, antitrust (competition) law should not undermine the social objectives recognised by the laws of those states. There is, however, space in those laws in which collective labour agreements may be subject to antitrust (competition) law scrutiny. 
